\title{
Differences in the Disaster-Preparedness Behaviors of the General Public and Professionals: Evidence from Sichuan Province, China
}

\author{
Zhuolin Yong ${ }^{1,+}$, Linmei Zhuang ${ }^{1,+}, \mathrm{Yi} \mathrm{Liu}^{1}$, Xin Deng ${ }^{2} \mathbb{C}$ and Dingde $\mathrm{Xu}^{3, * \mathbb{C}}$ \\ 1 College of Management, Sichuan Agricultural University, Chengdu 611130, China; \\ zhuolinyong@stu.sicau.edu.cn (Z.Y.); zhuanglinmei@stu.sicau.edu.cn (L.Z.); lyx1@stu.sicau.edu.cn (Y.L.) \\ 2 College of Economics, Sichuan Agricultural University, Chengdu 611130, China; dengxin@sicau.edu.cn \\ 3 Sichuan Center for Rural Development Research, College of Management, Sichuan Agricultural University, \\ Chengdu 611130, China \\ * Correspondence: dingdexu@sicau.edu.cn \\ + These authors contributed equally to this work and should be considered co-first authors.
}

Received: 14 June 2020; Accepted: 20 July 2020; Published: 21 July 2020

\begin{abstract}
Sichuan Province in China is one of the world's most earthquake-stricken areas. Wenchuan and Lushan Counties in Sichuan and other earthquake-stricken areas contain rural settlements subject to geological disasters and poverty. However, there is little research on the characteristics of disaster-preparedness behavior and whether these differ between professionals and the general public in rural settlements with high earthquake risk and poverty. Using survey data from 327 farmers in rural settlements affected by major earthquakes in Wenchuan and Lushan Counties, independent-sample t-tests and chi-squared tests were used to test for differences in the disaster-preparedness behaviors of professionals and the general public. The results show that (1) there were significant differences in emergency-disaster preparedness, knowledge and skills preparedness and overall disaster-prevention preparedness, and (2) there was no significant difference in physical disaster-prevention preparation. Based on these results, the study suggests policy directions for regional poverty alleviation, disaster prevention and reduction and disaster management.
\end{abstract}

Keywords: disaster preparedness; professionals; general public; earthquake; Sichuan Province; China

\section{Introduction}

The primary task of the rural-revitalization strategy of the 19th National Congress of the People's Republic of China (CPC) is to alleviate poverty and achieve prosperity for the poor by 2020 [1-8]. The 2019 central government document No. 1, "Prioritizing the development of agriculture and rural areas, and assisting agriculture, rural areas and farmers", clearly states that in order to promote rural development in a down-to-earth manner, it is necessary to speed up the completion of rural human settlements and public services [9-11]. Since the 18th National Congress of the CPC, China has made remarkable achievements in poverty alleviation [12]. The number of poor people in rural areas has decreased from 98.99 million to 17.13 million from 2012 to 2018-an average of nearly 14 million per year. However, by the end of 2018, there were still more than 17 million people living in poverty in rural areas-mainly in 14 contiguous impoverished mountainous areas $[13,14]$. Due to geology, topography and the level of local economic development, some settlements in these areas have a relationship between geological disasters and poverty $[15,16]$. Sichuan is a world-famous major earthquake area and is China's most serious earthquake disaster province [3,4]. From 2000 to 2017, 179 earthquakes of magnitude five or above occurred in China, resulting in a total of 488,437 casualties, of which $94.17 \%$ were in Sichuan Province. The direct economic losses from earthquake disasters in China amounted to 
1133.4 billion Yuan, of which 938.7 billion Yuan or $82.82 \%$, was in Sichuan Province [17]. The Wenchuan earthquake and Lushan earthquake are two major earthquakes with a magnitude of more than seven that caused about 450,000 casualties and direct economic losses of more than 900 billion Yuan [18,19]. Due to geological disasters and extreme weather conditions, poverty-prone populations in some Western mountain areas have returned to poverty at an average rate of $15-25 \%$ - or as high as $30-50 \%$ in some places $[20,21]$. Unlike the poverty effects caused by an extreme climate, geological disasters have the characteristics of occurring suddenly and being highly destructive [22,23]. The life savings of farmers can be wiped out instantly by such disasters, which have become a major way that farmers enter poverty or return to it after being previously lifted out of it [24,25]. Therefore, in the context of the "affluent life" proposed in the "rural revitalization strategy", and to achieve the goal of have a prosperous poor population by 2020, it is necessary to carry out research on the large group of farmers that live in regions prone to geological disasters and poverty.

When dealing with earthquake disasters in high-risk earthquake areas, adequate disasteravoidance preparation can reduce the threats to life and property loss and, thus, reduce the likelihood that farmers will return to poverty [26-29]. Many empirical studies have shown that residents' disaster preparedness is an effective means to deal with disaster shocks [30-35]. Disaster preparedness refers to the measures taken by residents to avoid disasters [36-38]. Different studies have different entry points for the measurement of residents' preparedness to avoid disasters [39-42]. Existing research has focused on protecting residents' life safety by measuring their disaster preparedness (e.g., [32-34]). Some scholars think that residents' preparedness for avoiding disasters is a one-dimensional concept, which can be directly measured by asking residents whether they have made adequate preparedness for avoiding disasters (e.g., [43]). Some scholars think that residents' preparedness for disaster avoidance is a multi-dimensional concept, which can be measured from multiple dimensions. For example, Onuma et al. [44] divided residents' preparedness for avoiding disasters into three dimensions of basic preparedness, energy/heat preparedness and assessment of specific design indicators for each dimension. At the same time, many studies believe that the residents' preparedness for avoiding disasters is simply material preparation, which is measured from the perspective of residents' material preparation. Among them, the most common way to measure disaster preparedness is to ask residents whether they have prepared emergency disaster kits (flashlights, radios, clean water) (e.g., [35,36,45,46]), buy insurance (e.g., [24,25]), if they had an escape plan (e.g., [39-42,47,48]) and reinforce houses (e.g., [38,49]). In addition, some scholars have noted that in addition to material preparation, residents' disaster preparedness, conscious disaster risk management behavior is also an effective means to deal with disaster impact (e.g., [21]). In general, the existing research provides useful reference for the measurement of disaster preparedness in this study. however, few research systems comprehensively consider three dimensions of emergency disaster preparedness, knowledge and skills preparedness and physical disaster prevention and set indicators to conduct systematic measurement of residents' behavior of disaster preparedness. In the face of an earthquake disaster, a family's disaster preparedness (such as preparing an emergency box) can increase their safety to some extent, but assistance for the reconstruction of their family life is limited. Determining the best way to construct a complete, efficient and resilient disaster prevention and control system that makes up for the shortcomings of current systems is of great significance to rural revitalization. It is a topic of high relevance to residents and governments of disaster areas and to society in general. Therefore, compared with the existing research, one of the marginal contributions of this research is to integrate the dimensions of residents' preparedness for earthquake disaster and measure it with specific indicators.

To date, a large number of studies have focused on earthquake disasters and to explore their disaster-preparedness behaviors and their influences (e.g., [40,41,50]). According to the general logic, if a region is well prepared for disaster, there should be no significant difference in preparedness between general public and professionals [42]. However, judging from the reality of disaster threat zones around the world, professionals tend to be better prepared than the general public. Identify the significant difference in disaster preparedness between professionals and the general public has two 
benefits, on one hand, it is helpful to identify the shortcomings of disaster preparedness of general public and formulate relevant policies to improve their disaster prevention and reduction capacity; on the other hand, we can find out the deficiencies in disaster preparedness of professionals and formulate corresponding policies to improve regional disaster prevention and reduction capacity. However, few studies have further analyzed the characteristics and differences of disaster preparedness between professionals and the general public. Professionals are generally full-time village cadres who have been systematically trained by professional institutions such as the state land administration (In China, the Land and Resources Administration of The People's Republic of China will organize professionals to participate in the training program of mass monitoring and mass prevention systems, systematically introduce experience in disaster prevention and reduction, and conduct some on-site disaster risk management exercises, so that professionals can better guide the general public in disaster risk management), and have the ability to protect their own lives and property, as well as the professional ability to observe the signs of earthquakes and warn the general public in a timely manner. The general public are local farmers in high-risk areas who do not have sufficient disaster awareness and preparedness. Compared with other studies, the second marginal contribution of this study is that the research objects are divided into professionals and general public, and the characteristics and differences of disaster preparedness of the two groups are systematically analyzed. Based on this, the objective of this study is to analyze the characteristics and differences of disaster preparedness between professionals and general public through the survey data of farmers in China's earthquake-stricken areas, so as to provide references for the formulation of regional disaster prevention and reduction policies.

Under the above background, this study focuses on the characteristics and differences of disaster preparedness between general public and professionals, in order to provide a reference for the formulation of policies related to poverty alleviation and disaster risk management of rural households in areas where earthquake disaster and poverty are intertwined. There are two key problems to be solved in this study:

(1) One is to analyze the characteristics of disaster preparedness of general public and professionals;

(2) The second is to compare whether there is a significant difference between general public and professionals in disaster preparedness. If there is, further analysis will be made on the difference between the two groups in disaster preparedness.

\section{Theoretical Basis and Variable Measure}

Based on the above analysis of introduction, referring to the disaster risk management literature, this study measures disaster-preparedness behavior in three dimensions: (1) emergency-disaster preparedness, (2) knowledge and skills preparedness and (3) physical disaster-prevention preparedness (Table 1). Among them, the selection of emergency-disaster preparedness dimension measurement indicators is based on references $[35,36,45,46]$, the selection of knowledge and skills preparedness dimension measurement indicators is based on references $[24,25,38,49]$ and the selection of knowledge and skills preparedness dimension measurement indicators is based on references [21,24].

Generally speaking, if a region is well prepared in disaster risk reduction and if disaster-related knowledge is well publicized, there should be no significant difference in disaster preparedness between professionals and the general public. Therefore, the following research assumptions were made in this study:

H1: There is no significant difference between the general public and professionals in their three dimensions of general disaster-preparedness behaviors (emergency-disaster preparedness, knowledge and skills preparedness, and physical disaster-prevention preparedness). 
Table 1. Measures of preparation behavior for earthquake disaster avoidance.

\begin{tabular}{|c|c|c|}
\hline Category & Variable & Measure Indicators $(0=\mathrm{No}, 1=$ Yes $)$ \\
\hline \multirow{3}{*}{$\begin{array}{l}\text { Emergency disaster } \\
\text { preparedness }\end{array}$} & Emergency supplies & $\begin{array}{l}\text { Does your home usually prepare disaster } \\
\text { emergency supplies? }\end{array}$ \\
\hline & Natural disaster insurance & $\begin{array}{c}\text { Does your family have enough natural } \\
\text { disaster insurance? }\end{array}$ \\
\hline & Preventive measures & Is your family taking preventive measures? \\
\hline \multirow{4}{*}{$\begin{array}{l}\text { Knowledge and skills } \\
\text { preparedness }\end{array}$} & Autonomous learning & $\begin{array}{l}\text { Do family members regularly learn disaster risk } \\
\text { reduction techniques? }\end{array}$ \\
\hline & $\begin{array}{l}\text { Knowledge acquisition } \\
\text { channel }\end{array}$ & Is there access to disaster information? \\
\hline & Training & $\begin{array}{c}\text { Has anyone in your family been trained in } \\
\text { disaster knowledge? }\end{array}$ \\
\hline & Escape drills & $\begin{array}{l}\text { Has anyone in your family ever participated in the } \\
\text { disaster escape drill organized by the village? }\end{array}$ \\
\hline $\begin{array}{l}\text { Physical disaster-prevention } \\
\text { preparedness }\end{array}$ & $\begin{array}{l}\text { Building reinforcement } \\
\text { Important item placement }\end{array}$ & $\begin{array}{l}\text { Is the home reinforced? } \\
\text { Do you keep important items in a safe place? }\end{array}$ \\
\hline
\end{tabular}

\section{Materials and Methodology}

\subsection{Introduction to the Research Area}

Sichuan province is one of the most earthquake-prone areas in China, the most famous of which are the Wenchuan earthquake in 2008 and the Lushan earthquake in 2012 [16]. According to statistics, the Wenchuan earthquake in 2008, with a magnitude of 8.0, destroyed more than 100,000 square kilometers and involved 237 districts and counties, causing nearly 460,000 casualties and direct economic losses of up to 845.215 billion Yuan [19]. With a magnitude of 7.0, the Lushan earthquake in 2012 mainly affected Lushan county, Baoxing County, Tianquan County and other counties, and affected a total of 383,000 people, with direct economic losses of up to 50 billion Yuan [16,19].

\subsection{Data Collection and Sampling Methods}

The data for this study were mainly obtained from a questionnaire survey conducted by the research team at Sichuan Agricultural University in July 2019 in the areas hardest hit by the 2008 Wenchuan earthquake and the 2012 Lushan earthquake. The research method was one-on-one face-to-face interviews, which mainly focused on residents' disaster risk perceptions and behavior choice of disaster preparedness. Each interview lasted about $1.5 \mathrm{~h}$. In order to ensure the typicality and representativeness of the samples, a stratified random sampling method was used to collect sample survey data $[24,51,52]$, as follows:

First, according to the situation of threatened population and social and economic development in the worst-hit areas in Wenchuan earthquake and Lushan earthquake, the surveyed sample areas and counties were determined. Pengzhou and Beichuan Qiang Autonomous County were selected as the sample counties (cities) that representing the ten Wenchuan earthquake-hit areas and counties, while Lushan and Baoxing County were selected representing the six Lushan earthquake- hit areas and counties. Second, according to the differences in the severity of the disaster, economic development levels of the districts and the distances from the centers of the districts, and two sample towns were randomly selected for each sample districts, resulting in a total of eight towns. Third, the study identified 16 sample villages ( 8 sample towns randomly selected 2 sample villages each) with similar indices and methods. Finally, according to the random number table set by the team and the list of farmers obtained from the village cadres, 20-23 households were randomly selected from each sample village as the sample farmers for the survey. After strict training, 13 researchers, led by village cadres, conducted one-on-one face-to-face surveys at the farmers' homes. In the end, a total of 327 valid questionnaires were obtained from 16 villages and eight towns in four districts and counties (Figure 1). Among them, thirty-four are professionals and the rest are members of the general public. 

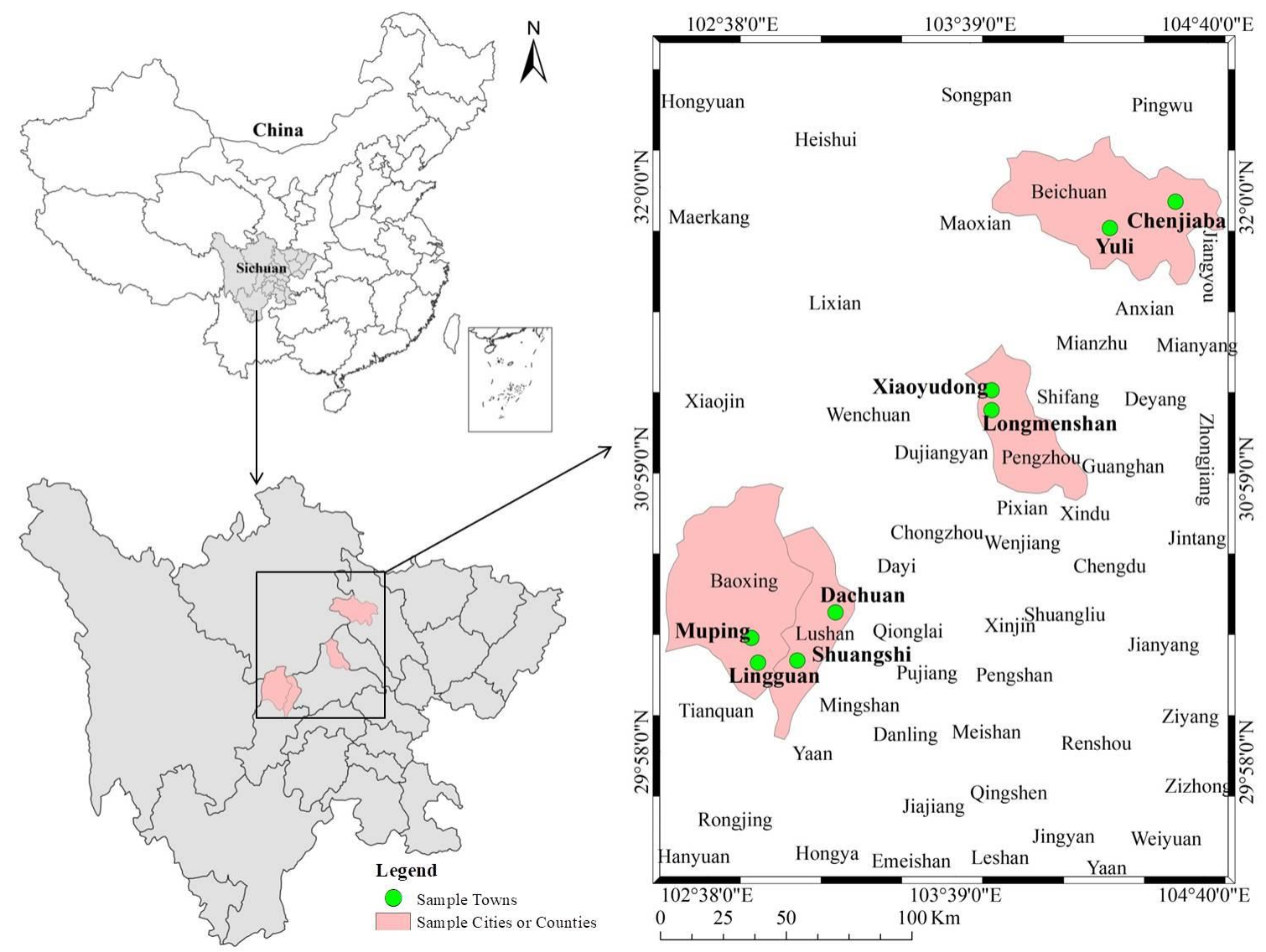

Figure 1. Distribution of survey counties and towns.

\subsection{Methods of Data Analysis}

This study attempts to explore the differences of disaster-preparedness behavior between general public and professionals in terms of emergency-disaster preparedness, knowledge and skills preparedness and physical disaster-prevention preparedness. The statistical analysis methods include descriptive statistical analysis, mean difference analysis of continuous variables in different categories (independent sample t-tests) and difference analysis of binary variables (chi-squared tests).

\section{Results}

\subsection{Differences in Emergency-Disaster Preparedness}

As can be seen from Table 2, in terms of the types of emergency supplies prepared, there were significant differences between general public and professionals in six specific items: water, food, emergency lights, first aid kits and manuals, important documents and cash and clothes. In the wake of a disaster, there were new and significant differences in ownership of radios, fire extinguishers, special items (such as medicine) and other items. In addition, the mean value, standard deviation and significant difference of these variables were significantly higher after a disaster than before one, indicating that the occurrence of a disaster prompts farmers to prepare disaster-avoidance items and enhance their awareness. 
Table 2. Differences in disaster-preparedness items between the general public and professionals before and after disasters.

\begin{tabular}{|c|c|c|c|c|c|c|}
\hline \multirow{2}{*}{ Variable } & \multicolumn{2}{|c|}{ Before Disaster } & \multicolumn{2}{|c|}{ After Disaster } & \multirow{2}{*}{$\begin{array}{c}\text { Significant } \\
\text { Difference } \\
\text { before Disaster }\end{array}$} & \multirow{2}{*}{$\begin{array}{c}\text { Significant } \\
\text { Difference after } \\
\text { Disaster }\end{array}$} \\
\hline & Mean & S.D. & Mean & S.D. & & \\
\hline Water & 0.08 & 0.27 & 0.23 & 0.42 & $-0.144^{* * *}$ & $-0.331^{* * *}$ \\
\hline Food & 0.09 & 0.28 & 0.21 & 0.41 & $-0.134 * * *$ & $-0.286^{* * *}$ \\
\hline Emergency light & 0.04 & 0.20 & 0.17 & 0.38 & $-0.116^{* * *}$ & $-0.301^{* * *}$ \\
\hline Radio & 0.00 & 0.00 & 0.02 & 0.13 & 0.000 & $-0.045^{*}$ \\
\hline First aid kit and manual & 0.01 & 0.08 & 0.06 & 0.23 & $-0.059 * * *$ & $-0.198^{* * *}$ \\
\hline Fire extinguisher & 0.01 & 0.08 & 0.06 & 0.23 & 0.007 & $-0.136^{* * *}$ \\
\hline $\begin{array}{l}\text { Special items } \\
\text { (e.g., medicine) }\end{array}$ & 0.02 & 0.13 & 0.11 & 0.32 & 0.020 & $-0.136^{* *}$ \\
\hline $\begin{array}{l}\text { Important documents } \\
\text { and cash }\end{array}$ & 0.01 & 0.11 & 0.08 & 0.27 & $-0.052^{* * *}$ & $-0.210^{* * *}$ \\
\hline Clothes & 0.04 & 0.19 & 0.16 & 0.36 & $-0.090^{* * *}$ & $-0.351 * * *$ \\
\hline
\end{tabular}

Note: ${ }^{*}, * * * * *$ are significant at the levels of $0.1,0.05$ and 0.01 , respectively.

\subsection{Differences in Knowledge and Skills Preparedness}

As can be seen from Table 3, while there was no significant difference between the two groups in their access to knowledge, there was a significant difference between the two specific ways in which they obtained paper-based seismic popular science data and accessed the websites of seismological departments.

Table 3. Differences in knowledge and skills preparedness between the general public and professionals.

\begin{tabular}{cccccc}
\hline Access to Knowledge & \multicolumn{2}{c}{ People in General } & $\begin{array}{c}\text { Mean of the } \\
\text { General Public }\end{array}$ & $\begin{array}{c}\text { Mean of } \\
\text { Professionals }\end{array}$ & Significance \\
\cline { 2 - 4 } & Mean & S.D. & 0.80 & 0.79 & 0.005 \\
News media & 0.80 & 0.40 & 0.39 & 0.62 & $-0.232^{* * *}$ \\
Paper seismic science materials & 0.41 & 0.49 & 0.05 & 0.21 & $-0.158^{* * *}$ \\
Earthquake department website & 0.06 & 0.25 & 0.14 & 0.18 & -0.033 \\
School education & 0.15 & 0.35 & 0.29 & 0.29 & -0.004 \\
WeChat/Weibo & 0.29 & 0.45 & 0.11 & 0.18 & -0.064 \\
Promotion of government & 0.12 & 0.32 & 0.10 & 0.06 & 0.037 \\
No channel & 0.09 & 0.29 &
\end{tabular}

\subsection{Differences in Physical Disaster-Prevention Preparedness}

As can be seen from Table 4, there was no significant difference between general public and professionals in physical disaster preparedness, among which the two indicators of building reinforcement and placing of important items were not significantly different. Some $59 \%$ of professionals reinforced their houses ( $3 \%$ higher than the general population), possibly because of the high cost of effective housing reinforcement and the low economic capacity of farmers in high-risk earthquake areas. This limits the opportunity for farmers to reinforce their houses. Some $59 \%$ of professionals kept important items in a safe place ( $4 \%$ less than the general population), probably due to the general high awareness of property protection among farmers.

\subsection{Overall, Disaster Preparedness Differences}

It can be seen from Table 4 that there was a significant difference in the disaster-preparedness behaviors of farmers (general public and professionals) in poverty-stricken, earthquake-prone regions, which is not consistent with the hypothesis.

As can be seen from Table 4, there was a significant difference between general public and professionals in emergency-disaster preparedness, which is reflected in the preparation of emergency goods and disaster prevention and mitigation measures, but there was no significant difference in whether or not 
they purchased natural disaster insurance. Specifically, $56 \%$ of professionals had emergency supplies, which is $35 \%$ higher than the general public; $94 \%$ of professionals had taken preventive measures, which is $21 \%$ higher than the general public. However, only $27 \%$ of the general public had taken out natural disaster insurance, which is almost the same rate as for professionals. This may be due to a low awareness of disaster risk among local farmers and the low amount of insurance coverage offered, which results in low enthusiasm to take out insurance.

Table 4. Differences in disaster preparedness between the general public and professionals.

\begin{tabular}{|c|c|c|c|c|c|c|}
\hline \multirow{2}{*}{ Category } & \multirow{2}{*}{ Variable } & \multicolumn{2}{|c|}{ General Public } & \multicolumn{2}{|c|}{ Professionals } & \multirow{2}{*}{ Significance } \\
\hline & & Mean & S.D. & Mean & S.D. & \\
\hline \multirow{3}{*}{$\begin{array}{c}\text { Emergency-disaster } \\
\text { preparedness }\end{array}$} & Emergency suppliers & 0.21 & 0.41 & 0.56 & 0.50 & $0.000^{* * *}$ \\
\hline & $\begin{array}{l}\text { Natural disaster } \\
\text { insurance }\end{array}$ & 0.27 & 0.45 & 0.29 & 0.46 & 0.794 \\
\hline & Preventive measures & 0.73 & 0.44 & 0.94 & 0.24 & $0.007^{* * *}$ \\
\hline \multirow{4}{*}{$\begin{array}{l}\text { Knowledge and } \\
\text { skills preparedness }\end{array}$} & Autonomous learning & 0.58 & 0.49 & 0.91 & 0.29 & $0.000^{* * *}$ \\
\hline & $\begin{array}{c}\text { Knowledge acquisition } \\
\text { channel }\end{array}$ & 0.88 & 0.32 & 0.97 & 0.17 & 0.112 \\
\hline & Training & 0.41 & 0.49 & 0.85 & 0.36 & $0.000^{* * *}$ \\
\hline & Escape drill & 0.52 & 0.50 & 0.88 & 0.33 & $0.000^{* * * *}$ \\
\hline \multirow{2}{*}{$\begin{array}{c}\text { Physical } \\
\text { disaster-prevention } \\
\text { preparedness }\end{array}$} & Building reinforcement & 0.56 & 0.50 & 0.59 & 0.50 & 0.780 \\
\hline & $\begin{array}{l}\text { Important items } \\
\text { placement }\end{array}$ & 0.63 & 0.48 & 0.59 & 0.50 & 0.622 \\
\hline \multicolumn{2}{|c|}{ Emergency-disaster preparedness } & 0.41 & 0.28 & 0.60 & 0.29 & $0.0002^{* * *}$ \\
\hline \multicolumn{2}{|c|}{ Knowledge and skills preparedness } & 0.60 & 0.31 & 0.90 & 0.22 & $0.0000^{* * *}$ \\
\hline \multicolumn{2}{|c|}{ Physical disaster-prevention preparedness } & 0.60 & 0.35 & 0.59 & 0.31 & 0.8845 \\
\hline \multicolumn{2}{|c|}{ Overall disaster-prevention preparedness } & 0.53 & 0.23 & 0.70 & 0.20 & $0.0001^{* * *}$ \\
\hline
\end{tabular}

Note: ${ }^{* * *}$ is significant at the levels of 0.01 .

It can be seen from Table 4 that there were significant differences between general public and professionals in knowledge and skills preparation, which are reflected in independent learning, training and escape drills, while there were no significant differences in knowledge acquisition channels. Specifically, $85 \%$ of professionals participated in disaster prevention skills training ( $44 \%$ more than the general public); and $88 \%$ of professionals participated in escape drills organized by the village (36\% more than the general public). The proportion of professionals with access to knowledge was $97 \%$, while that of the general public was $88 \%$. The difference was not significant, possibly because the survey sites were all in the main earthquake area or area of influence, and the local village committee provided sufficient access to earthquake disaster knowledge to ensure that most people could access relevant knowledge.

\section{Conclusions}

Through the previous analysis, we get the following main conclusions:

(1) There were significant difference between the general public and professionals in emergencydisaster preparedness, knowledge and skills preparedness and overall disaster-prevention preparedness;

(2) There was no significant difference between the general public and professionals in physical disaster-prevention preparedness.

\section{Policy Implications}

The disaster and poverty situation in Sichuan Province is quite severe and many large earthquakes have occurred, which has aroused wide public concern. This is also one of the most important challenges in poverty alleviation in the southwestern mountainous areas. Therefore, earthquake-related disaster prevention and mitigation work is particularly important, even though most earthquake-prone areas are 
equipped with relevant professionals. However, there is a significant difference between professionals and the general public in disaster-preparedness behavior. Based on the above conclusions, the following countermeasures and suggestions are proposed for disaster prevention and reduction by farmers in areas where earthquakes and poverty are interwoven.

(1) Professionals should strengthen their awareness of insurance participation and disaster crises. Professionals have rich knowledge reserves for the cognition and perception of earthquake disasters and have relevant scientific literacy that helps in the understanding of disaster-avoidance articles, escape behavior and reducing loss of life and property after disasters. However, they have some shortcomings in their awareness and purchasing of natural disaster insurance, reinforcement of houses and placement of important items. The government could start by raising the awareness of insurance professionals themselves and general awareness of disaster crises. This could be strengthened by advising insurance companies to increase their types and amounts of natural disaster insurance offered, increase the publicity of natural disaster insurance, and increase subsidies for insurance and house reinforcement.

(2) The general public should increase their initiatives in disaster prevention and preparedness. There are significant differences between the emergency-disaster preparedness and the knowledge and skills preparedness of the general public in the face of disasters, especially in the following five aspects: emergency supplies preparedness, preparedness for preventive measures, self-study and participation in training and escape drills. The difference between the two groups in these five aspects is, in the final analysis, the difference between a subjective initiative in disaster preparedness and a sense of disaster avoidance. The government may consider promoting the initiative of the general public to avoid disasters. This can be done by promoting education on disaster prevention, establishing grassroots disaster prevention groups and establishing village disaster-prevention preparedness and supervision committees.

(3) The government's disaster prevention policy-making should expand its audience appropriately. The government formulates disaster prevention policies and measures and systematically trains full-time village cadres as professionals for the ultimate purpose of ensuring that there is no significant difference between professionals and the general public in all aspects of disaster prevention and reduction. However,-according to the research results-the overall difference between the two groups is still significant, indicating that the range of people reached by existing policies and measures is small. In future policy formulation, the audience should be expanded appropriately to make up for the shortcomings of the general public in disaster prevention and mitigation, so as to eliminate the significant difference between the two groups.

(4) The system of settlement disaster prevention and reduction should be improved. The government can jointly build a disaster prevention and mitigation system for settlements based on the three aspects of emergency-disaster preparedness, knowledge and skills preparedness and physical disaster prevention. It should give full play to the leading and exemplary role of professionals in emergency-disaster preparedness and knowledge and skills preparedness, actively organize knowledge-based training on natural disasters such as earthquakes, organize regular earthquake escape drills, regularly inspect the soundness of houses prepared by farmers for disaster mitigation, and give special disaster-prevention guidance to poor farmers. We will appropriately increase subsidies for settlement in mountainous areas, improve farmers' production conditions and transportation environment; strengthen farmers' own capacity to consolidate the achievements of poverty alleviation.

Author Contributions: Conceptualization, D.X.; formal analysis, D.X.; funding acquisition, D.X.; investigation, Z.Y., L.Z. and Y.L.; methodology, Z.Y., L.Z., Y.L. and X.D.; writing-original draft, Z.Y. and D.X.; writing一review \& editing, Z.Y. and D.X. All authors have read and agreed to the published version of the manuscript.

Funding: This research was funded by the National Natural Science Foundation of China (No. 41801221), the Dual Support Plan of Sichuan Agricultural University (Grant No. 1921993045), the Innovation Training Program of Sichuan Agricultural University in 2019 (No. 2019106226105) and Undergraduate Research Interest Cultivation Program in 2020 of the Sichuan Agricultural University (No. 2020466; No. 2020465). 
Acknowledgments: We gratefully acknowledge financial support from the National Natural Science Foundation of China (No. 41801221), the Dual Support Plan of Sichuan Agricultural University and the Undergraduate Research Interest Cultivation Program in 2020 of the Sichuan Agricultural University (No. 2020466; No. 2020465). The authors also extend great gratitude to the anonymous reviewers and editors for their helpful review and critical comments.

Conflicts of Interest: The authors declare no conflict of interest.

\section{References}

1. Guo, S.L.; Lin, L.; Wei, Y.L.; Xu, D.D.; Li, Q.Y.; Liu, S.Q. Interactions between sustainable livelihood of farm household and agricultural land transfer in the mountainous and hilly regions of Sichuan, China. Sustain. Dev. 2019, 27, 725-742. [CrossRef]

2. Guo, S.L.; Li, C.J.; Wei, Y.L.; Zhou, K.; Liu, S.Q.; Xu, D.; Li, Q.Y. Impact of land expropriation on farmers' livelihoods in the mountainous and hilly regions of Sichuan, China. J. MT Sci. 2019, 16, 2484-2501. [CrossRef]

3. Xu, D.D.; Deng, X.; Guo, S.L.; Liu, S.Q. Labor migration and cropland abandonment in rural China: Empirical results and policy implications. J. Environ. Manag. 2019, 232, 738-750. [CrossRef] [PubMed]

4. Huang, K.; Deng, X.; Liu, Y.; Yong, Z.; Xu, D. Does off-farm migration of female laborers inhibit land transfer? Evidence from Sichuan Province, China. Land 2020, 9, 14. [CrossRef]

5. Xu, D.D.; Deng, X.; Guo, S.L.; Liu, S.Q. Sensitivity of livelihood strategy to livelihood capital: An empirical investigation using nationally representative survey data from rural China. Soc. Indic. Res. 2019, 144, 113-131. [CrossRef]

6. Deng, X.; Xu, D.D.; Zeng, M.; Qi, Y.B. Does internet use help reduce rural cropland abandonment? Evidence from China. Land Use Policy 2019, 89, 104243. [CrossRef]

7. Xu, D.; Ma, Z.; Deng, X.; Liu, Y.; Huang, K.; Zhou, W.; Yong, Z. Relationships between land management scale and livelihood strategy selection of rural households in China from the perspective of family life cycle. Land 2020, 9, 11. [CrossRef]

8. Xu, D.; Yong, Z.; Deng, X.; Zhuang, L.; Qing, C. Rural-urban migration and its effect on land transfer in rural China. Land 2020, 9, 81. [CrossRef]

9. Deng, X.; Xu, D.D.; Zeng, M.; Qi, Y.B. Does early-life famine experience impact rural land transfer? Evidence from China. Land Use Policy 2019, 81, 58-67. [CrossRef]

10. Peng, L.; Tan, J.; Lin, L.; Xu, D.D. Understanding sustainable disaster mitigation of stakeholder engagement: Risk perception, trust in public institutions, and disaster insurance. Sustain. Dev. 2019, 27, 885-897. [CrossRef]

11. Peng, L.; Xu, D.D.; Wang, X.X. Vulnerability of rural household livelihood to climate variability and adaptive strategies in landslide-threatened western mountainous regions of the Three gorges reservoir area, China. Clim. Dev. 2019, 11, 469-484. [CrossRef]

12. Deng, X.; Xu, D.; Zeng, M.; Qi, Y. Landslides and cropland abandonment in China's mountainous areas: Spatial distribution, empirical analysis and policy implications. Sustainability 2018, 10, 3909. [CrossRef]

13. Li, Y.L. The strategy of rural revitalization-A new blueprint for rural development. Great Western Dev. 2018, 3, 114-117. (In Chinese)

14. Xu, D.D.; Deng, X.; Hang, K.; Liu, Y.; Yong, Z.L.; Liu, S.Q. Relationships between labor migration and cropland abandonment in rural China from the perspective of village types. Land Use Policy 2019, 88, 104-164. [CrossRef]

15. Xu, D.D.; Guo, S.L.; Xie, F.T.; Liu, S.Q.; Cao, S. The impact of rural laborer migration and household structure on household land use arrangements in mountainous areas of Sichuan Province, China. Habitat Int. 2017, 70 , 72-80. [CrossRef]

16. Xu, D.D.; Peng, L.; Liu, S.Q.; Su, C.J.; Wang, X.X.; Chen, T.T. Influences of sense of place on farming households' relocation willingness in areas threatened by geological disasters: Evidence from China. J. Disaster Risk Sci. 2017, 8, 16-32. [CrossRef]

17. Xu, D.; Liu, Y.; Deng, X.; Qing, C.; Zhuang, L.; Yong, Z.; Huang, K. Earthquake disaster risk perception process model for rural households: A pilot study from southwestern China. Int. J. Environ. Res. Public Health 2019, 16, 4512. [CrossRef]

18. CNSB (China National Statistical Bureau). China Yearbook of Household Survey in 2017; China Statistical Press: Beijing, China, 2018. 
19. Xu, D.; Yong, Z.; Deng, X.; Liu, Y.; Huang, K.; Zhou, W.; Ma, Z. Financial preparation, disaster experience, and disaster risk perception of rural households in earthquake-stricken areas: Evidence from the Wenchuan and Lushan earthquakes in China's Sichuan Province. Int. J. Environ. Res. Public Health 2019, 16, 3345. [CrossRef]

20. Xu, D.D.; Peng, L.; Liu, S.Q.; Su, C.J.; Wang, X.X.; Chen, T.T. Influences of migrant work income on the poverty vulnerability disaster threatened area: A case study of the Three Gorges Reservoir area, China. J. Disaster Risk Red. 2017, 22, 62-70. [CrossRef]

21. Xu, D.D.; Peng, L.; Liu, S.Q.; Su, C.J.; Wang, X.X.; Chen, T.T. Influences of mass monitoring and mass prevention systems on peasant households' disaster risk perception in the landslide-threatened Three Gorges Reservoir area, China. Habit. Int. 2016, 58, 23-33. [CrossRef]

22. Cao, M.T.; Xu, D.D.; Xie, F.T.; Liu, E.L.; Liu, S.Q. The influence factors analysis of households' poverty vulnerability in southwest ethnic areas of China based on the hierarchical linear model: A case study of Liangshan Yi Autonomous Prefecture. Appl. Geogr. 2016, 66, 144-152. [CrossRef]

23. Xu, D.D.; Zhang, J.F.; Rasul, G.; Liu, S.Q.; Xie, F.T.; Cao, M.T.; Liu, E. Household livelihood strategies and dependence on agriculture in the mountainous settlements in the Three Gorges Reservoir area, China. Sustainability 2015, 7, 4850-4869. [CrossRef]

24. Xu, D.D.; Liu, E.L.; Wang, X.X.; Tang, H.; Liu, S.Q. Rural households' livelihood capital, risk perception, and willingness to purchase earthquake disaster insurance: Evidence from southwestern China. Int. J. Environ. Res. Public Health 2018, 15, 1319. [CrossRef] [PubMed]

25. Xu, D.D.; Peng, L.; Liu, S.Q.; Wang, X.X. Influences of risk perception and sense of place on landslide disaster preparedness in southwestern China. J. Disaster Risk Sci. 2018, 9, 167-180. [CrossRef]

26. Adams, R.M.; Eisenman, D.P.; Glik, D. Community advantage and individual self-efficacy promote disaster preparedness: A multilevel model among persons with disabilities. Int. J. Environ. Res. Public Health 2019, 16, 2779. [CrossRef]

27. Armas, I. Earthquake risk perception in Bucharest, Romania. Risk Anal. 2006, 26, 1223-1234. [CrossRef]

28. Becker, J.S.; Paton, D.; Johnston, D.M.; Ronan, K.R. A model of household preparedness for earthquakes: How individuals make meaning of earthquake information and how this influences preparedness. Nat. Hazards 2012, 64, 107-137. [CrossRef]

29. KC, A.; Gan, C.C.R.; Dwirahmadi, F. Breaking through barriers and building disaster mental resilience: A case study in the aftermath of the 2015 Nepal earthquakes. Int. J. Environ. Res. Public Health 2019, 16, 2964. [CrossRef]

30. Donner, W.R.; Lavariega-Montforti, J. Ethnicity, income, and disaster preparedness in deep South Texas, United States. Disasters 2018, 42, 719-733. [CrossRef]

31. Fung, O.W.M.; Loke, A.Y.; Lai, C.K.Y. Disaster preparedness among Hong Kong nurses. J. Adv. Nurs. 2008, 62, 698-703. [CrossRef]

32. Godschalk, D.; Rose, A.; Mittler, E.; Porter, K.; West, C.T. Estimating the value of foresight: Aggregate analysis of natural hazard mitigation benefits and costs. J. Environ. Plan. Manag. 2009, 52, 739-756. [CrossRef]

33. Hoffmann, R.; Muttarak, R. Learn from the past, prepare for the future: Impacts of education and experience on disaster preparedness in the Philippines and Thailand. World Dev. 2017, 96, 32-51. [CrossRef]

34. Samaddar, S.; Murase, M.; Okada, N. Information for disaster preparedness: A social network approach to rainwater harvesting technology dissemination. J. Disaster Risk Sci. 2014, 5, 95-109. [CrossRef]

35. Doyle, E.E.H.; McClure, J.; Potter, S.H.; Becker, J.S.; Johnston, D.M.; Lindell, M.K.; Johal, S.; Fraser, S.A.; Coomer, M.A. Motivations to prepare after the 2013 Cook Strait Earthquake, NZ. Int. J. Disaster Risk Red. 2018, 31, 637-649. [CrossRef]

36. Lindell, M.K.; Perry, R.W. Household adjustment to earthquake hazard: A review of research. Environ. Behav. 2000, 32, 461-501. [CrossRef]

37. Lindell, M.K.; Prater, C.S.; Wu, H.C.; Huang, S.K.; Johnston, D.M.; Becker, J.S.; Shiroshita, H. Immediate behavioural responses to earthquakes in Christchurch, New Zealand, and Hitachi, Japan. Disasters 2016, 40, 85-111. [CrossRef]

38. Miceli, R.; Sotgiu, I.; Settanni, M. Disaster preparedness and perception of flood risk: A study in an alpine valley in Italy. J. Environ. Psychol. 2008, 28, 164-173. [CrossRef]

39. Hong, Y.X.; Kim, J.S.; Xiong, L.H. Media exposure and individuals' emergency preparedness behaviors for coping with natural and human-made disasters. J. Environ Psychol. 2019, 63, 82-91. [CrossRef] 
40. Sun, Y.Y.; Sun, J.K. Perception, preparedness, and response to tsunami risks in an aging society: Evidence from Japan. Saf. Sci. 2019, 118, 466-474. [CrossRef]

41. Sun, L.; Su, G.; Tian, Q.; Qi, W.; Liu, F.; Qi, M.; Li, R. Religious belief and Tibetans' response to earthquake disaster: A case study of the 2010 Ms 7.1 Yushu earthquake, Qinghai Province, China. Nat. Hazards 2019, 99, 141-159. [CrossRef]

42. Wu, Y. Experts and the public: A review of the implications of the health risk perception gap study. J. Southwest Univ. Natl. (Hum. Soc. Sci. Ed.) 2007, 10, 160-163. (in Chinese).

43. Kirschenbaum, A.A.; Rapaport, C.; Canetti, D. The impact of information sources on earthquake preparedness. J. Disaster Risk Reduct. 2017, 21, 99-109. [CrossRef]

44. Onuma, H.; Shin, K.J.; Managi, S. Household preparedness for natural disasters: Impact of disaster experience and implications for future disaster risks in Japan. J. Disaster Risk Reduct. 2017, 21, 148-158. [CrossRef]

45. Cretikos, M.; Eastwood, K.; Dalton, C.; Merritt, T.; Tuyl, F.; Winn, L.; Durrheim, D. Household disaster preparedness and information sources: Rapid cluster survey after a storm in New South Wales, Australia. BMC Public Health 2008, 8, 195. [CrossRef] [PubMed]

46. Hassan Gillani, A.; Mohamed Ibrahim, M.I.; Akbar, J.; Fang, Y. Evaluation of disaster medicine preparedness among healthcare profession students: A cross-sectional study in Pakistan. Int. J. Environ. Res. Public Health 2020, 17, 2027. [CrossRef]

47. Sudo, N.; Mashiro, G.; Beppu, S.; Hakamata, R. A training program to enhance disaster preparedness of group companies in the Tokyo metropolitan area. Int. J. Environ. Res. Public Health 2019, 16, 4871. [CrossRef]

48. Burke, S.; Bethel, J.W.; Britt, A.F. Assessing disaster preparedness among latino migrant and seasonal farmworkers in eastern north Carolina. Int. J. Environ. Res. Public Health 2012, 9, 3115-3133. [CrossRef]

49. Kim, Y.-C.; Kang, J. Communication, neighbourhood belonging and household hurricane preparedness. Disasters 2010, 34, 470-488. [CrossRef]

50. Rodgers, J.; Su, G.; Qi, W.; Milledge, D.; Densmore, A.; Davis, C.; Guo, C. Creating an earthquake scenario in China: A case study in Weinan City, Shaanxi province. Int. J. Disaster Risk Reduct. 2020, 42, 101-305. [CrossRef]

51. Xu, D.D.; Zhou, W.F.; Deng, X.; Yong, Z.L.; Qing, C. Information credibility, disaster risk perception and evacuation willingness of rural households in China. Nat. Hazards 2020, 1-18. [CrossRef]

52. Xu, D.; Qing, C.; Deng, X.; Yong, Z.; Zhou, W.; Ma, Z. Disaster risk perception, sense of pace, evacuation willingness, and relocation willingness of rural households in earthquake-stricken areas: Evidence from Sichuan Province, China. Int. J. Environ. Res. Public Health 2020, 17, 602. [CrossRef] 